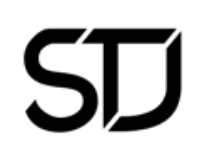

\title{
John Calvin on God's calling: Service in the church and the world
}

\author{
Zeze, Willie SD \\ Mukhanyo Theological College, Pretoria, South Africa \\ willy.zeze@gmail.com
}

\begin{abstract}
Building on Martin Luther's (1483-1546) view that the whole world could be filled with the service to God, this article is an investigation of John Calvin's (1509-1564) assertion that every person's occupation is a post and a station assigned to him by God. Although some people, as others did to Calvin and other reformers, may argue that the article demonstrates insensitivity to the unemployed, I have argued that restricting the word "calling" to ecclesiastical function always distorts the biblical meaning of the term. The central question in this article is simply: What can the today's society learn from Calvin's doctrine of occupational calling? Said differently, if Calvin and other Reformers were still alive what could they say to today's politicians, legislators, businessmen, bankers, traders, scientists, judges and other public servants? Noting that the medieval society completely distorted the biblical truth of calling, this paper calls for a simple return to Calvin's doctrine of vocation calling. The discussion walks from Biblical texts through the key developments in theology particularly related to how vocation was understood in the early and medieval churches that culminated in the Reformers' view. The article concludes by offering various suppositions of what Calvin could have commended to us today.
\end{abstract}

\section{Keywords}

God; Calvin; calling; service; church; world

\section{Introduction}

At the onset it is necessary to point out that concept of calling originated in the mind of God and it was revealed through the Old Testament and New Testament writers. Shortly, we will examine how the medieval church distorted its meaning and the way Calvin and other Reformers restored it. This article endorses a simple return to the Calvin's doctrine of calling. 


\section{The Bible as a frame reference to Calvin's doctrine of occupational calling}

The Latin word "vocation" which means simply "calling," is a constant theme for this article as it was in Christian communities and other thinkers throughout the history of the Church. But the question is: what is calling? Os Guinness, in his book The Call, defines calling this way:

Calling is the truth that God calls us to himself so decisively that everything we are, everything we do, and everything we have is invested with a special devotion, dynamism and direction and lives out as a response to his summons and service (Guinness 2003:29).

Apparently, calling is not limited to ecclesiastical responsibilities, even the Bible has much to say about it. First, the verb to call is used in the sense to name of things ${ }^{1}$ (Gen 1:5-30), and animals (Gen 2:9; 25:26; 30:6-24) of a city (1 Sam 5:9), of qualities of sacred days, things and of human beings (Is 35:8; Ex 12:16; 20:4-9). Second, "to call" also means to summon or invite like the case of God's call of Adam and Eve after the fall (Gen 3:9) Moses's call of elders (Ex 19:7) and of Prophet Joel 1:14's command to call a solemn assembly (Calvin 1958:26,27). Third, the same verb has a sense of God's calling to worship and pray to Him (Gen 4:26; Ps 79:6; 105:1; Jer 10:25. Fourth, God calls people to service - for example the call of Abraham (Gen 12:1-3), the call of Moses to lead the Israelites out of Egypt and in the wilderness (Ex 3:4-22). God's is evident in the call of Joshua (Josh 1:1-9), Samuel (1 Sam 3:1-10), Isaiah (Is 6); Jeremiah (Jer 1:4-9); (Ezek 3); Jonah (Jon1:2). Fifth, especially noticeable is God's calls of people to specific tasks or occupations as He did with Adam, Noah, Moses, prophets and disciples.

All the Old Testament meanings of the verb "to call" or "calling" are also found in the New Testament. Let's cite few references. First, calling in the sense of naming is evident in infancy narratives (Mt 1:21; Lk 1:60; 2:21. Second, the sense of calling has a meaning mostly in the parables of the great banquet (Lk 14:16-25) and the marriage feast (Mt 22:2-10). Third, Jesus Christ's choice of the twelve disciples (Mt 10:2; Lk 6:14ff) and the Holy Spirit's call of Barnabas and Saul to be missionaries and the later to be an apostle (Rom 1:1; 1 Cor 1:1; Acts 13:2) are clearly expressed as calling.

1 To call means to name and to name means to call into being or to make. 
Fourth, true followers of Jesus Christ are the people whom He has called and who are rightly called by His name (Rom 8:28; Gal 1:6; 1 Thess 2:12 and 1 Pet 1:15). Fifth, calling on the name of the Lord Jesus Christ a quotation of Prophet Joe 1:14 is clearly restated both in Acts 2:21 and Romans 10:13.

Putting these points together should lead us to preliminarily conclude that God calls people to work. Paul in his letter to Colossian 3:17 Church writes: "Whatever you do, in word or deed, do everything in the name of the Lord" (Calvin 1979:218). He is one the one who lawfully orchestrated social, political, economic, legal and Christian events leading every person to a position and place. To that extent, every lawful occupation represents God's calling.

Although Jesus gives no general call for all Christians to give up every day work, much of his teachings are drawn on themes from the world of everyday work. He makes general references to a variety of vocational calling particularly in his parables and illustrative stories of a teacher and student, a servant and a master, a famer and a tenant (Mt 10:23-24), fishermen (Mt 4:18ff) tax collectors (Lk 19:1-10), money lenders, money changers and traders (Lk 19:11ff; Jn 2:12-16), governors and kings (Lk 2:13).

Even New Testament writers hold a high view of occupation calling. Christians have obligation to work and work hard (1 Thess 4:11; 2 Thess 3:8-12 and render services to supervisors as to God (Eph 5:5-9). In his letter to the Colossian church, he writes: "Whatever you do, in word or deed, does everything in the name of the Lord" (Col 3:17). It is apparent from his own writings that he continued in his trade as a tentmaker during his church planting ministry. Perhaps one may speculate that Paul's tent making ministry was part of his occupational calling.

The foregoing Scriptures substantiate Calvin's assertion that God places individuals where $\mathrm{He}$ wants them to be and that that every person's occupation is a post and a station assigned to him by God and each person should retain the place in life that the Lord assigned to him and to which God has called (1 Cor 7:17). ${ }^{2}$ We now examine how the biblical meaning of vocational calling distorted in history. 


\section{How the medieval church crippled the meaning of calling}

Walking through some key developments related to how vocational calling was understood from the times of Eusebius and Augustine in the early church to pre-reformation era that also culminated in the Reformers like Luther and Calvin is essentially important at this point. Three factors might have contributed to the shift of the meaning. First, in trying to find an explanation for the meaning of God's calling, during medieval and middle Ages, Christian sects divided the world into sacred and secular and classified Christians into first rate (clergy) and second rate with subordination of the laity (Ray Petry 1988:343). Second, it was the rise of monastic spirituality which regarded vocation as a calling out of the world into isolation (monastery). Third, it was the theology of certain Church fathers, for example Eusebius and Augustine of Hippo. Writing on the same, Alister McGrath comments on the remarks made by Eusebius, one of the renowned Church fathers:

For Eusebius of Caesarea, the perfect Christian was one devoted to serving God, untainted by physical labour. Those who chose to work for a living were second-rate Christians ... To live and work in the world was to forfeit a first-rate Christian calling with all that is implied (McGrath 1991:223).

It was during this that the term "calling" was applied only to monks, priests, and bishops. ${ }^{3}$ In his personal blog, Hugh Weichel quotes Henlee Barnett explaining:

By the time Christianity became the official religion of the Roman Empire, the distinction between clergy and laity was wellestablished. With the establishment of celibacy for the clergy in the 11 th century, this demarcation was complete, and the laity were relegated to second-class status in the church (Whelchel 2016).

Brian Walsh et al (1984:99) also observes that Augustine of Hippo had a high view on the work of farmers, craftsmen and merchants, though the contemplative life, for him, was of a higher order (Walsh and Middleton 1984:99). Gregg Singer (1974: vii) alludes that although Augustine's 
writings influenced many, including Luther and Calvin, he did very little to change the perception of occupational calling. As a result, the medieval church continued restricting calling to ecclesiastical function until the $16^{\text {th }}$ century when Reformers restored a sense of dignity and biblical worth.

\section{How Calvin restored the doctrine of vocational calling}

Having considered how the church and society distorted the meaning of the calling, we need do no more here than briefly examine how Calvin and other reformers restored the biblical meaning. On the eve of Reformation, the notion of calling was restricted to numerous numbers of orders like bishops, priest, deacons, monks and nuns (Claar et al (2007:166). By then the name "estate" was used to denote one's occupation or station in life whereas calling was reserved for the ecclesiastical functions. Against this Calvin, along with Luther and others redefined and rediscovered the doctrine of occupational calling. Luther's supreme achievement in regard to the doctrine of vocation was to obliterate the division between sacred and secular spheres in line with his interpretation of the concept of the priest of all believers (1 Peter 2:9), against the medieval church theology which viewed calling as the prerogative of clerics and monks. He believed that one's primary calling was to serve God as a Christian and that from there follows the call to serve everyone in the world (Whelchel 2016). It is evident that Luther's careful and creative thinking significantly impacted his point of departure of his doctrine of vocation:

A cobbler, a smith, a farmer, each has the work and office of his trade, and yet they are all alike consecrated priests and bishops, and every one by means of his own work or office must benefit and serve every other, that in this way many kinds of work may be done for the bodily and spiritual welfare of the community, even as all the members of the body serve one another (Luther 1520).

On the contrary, Calvin's point of departure of his teaching on occupational calling was his doctrine of God's sovereignty, predestination, providence and Christian life. In the same vein Szemerei gives a further comment:

Expanding on the five Solas of the Reformation in his greater theology, Calvin's concept of vocation drew on points he made to 
explain his other more notable doctrines. He developed theologies of predestination, election, providence, and common grace (Szemerei 2008:47).

Calvin maintains that that every detail of people's social, political, economic and Christian life is directly predestined by God. Commenting on Mt 10:30, he writes:

After learning that there is a Creator, (faith) must forthwith infer that he is also a Governor and Preserver, and that, not by producing a kind of general motion in the machine of the globe as well as in its parts, but by a special providence sustaining, cherishing, superintending, all the things which he has made, to the very minutest, even to a sparrow. Again, 'Therefore, let us realise, when there are poor and rich people in this world, that God ordains it so, and that it comes from his providence (Calvin 1995:307).

These comments are echoed in Calvin's Institutes particularly where he writes:

We are God's: let us therefore live for him and die for him. We are God's let his wisdom and will therefore rule out actions. We are God's, let all the parts of our life accordingly strive toward him as our only lawful goal (Rom 14:8, 1 Cor 6:19). On how much that man has profited who, having been taught that he is not his own, has taken away dominion and rule from his own reason that he may yield it to God! (Institutes 3.7.15, 19).

When we connect Calvin's doctrine of predestination to doctrine of vocational calling particularly his notion that God predestines some to life and others to damnation, we will realize that Calvin is insensitive in the situation where there is high percentage of unemployed people.

But against the medieval theology that taught that churches and monasteries were the only holy places where first-rate Christians: priests, monks and nuns could get closer to God, Calvin, like other reformers believe that God made the entire world to lecture all of us, and that under His tutelage this world is a school room in which heavenly truths are accurately taught (Institutes 1.4.6) and added that all life is a religious, objecting to the prevalent thinking that only religious workers have a calling. 
In Luther's view, God calls us to express our faith in Him and His righteousness by loving service within the social communities to which we already belong through the responsibilities that arise from our stations and offices within them (Steven Hein 1999:121). For Calvin, calling is connected to a proper ordering of human life, maintaining law and order in response to threats, confusion, chaos, and corruption and reflecting a godly way of life in public spheres. In this regard Calvin appeals for a degree of transparency and accountability in all spheres of life.

\section{Calvin's grounds for viewing occupation as God's calling}

Against the medieval belief that only some parts of the world and offices are sacred, according to Calvin, the entire world, and not part of it, is a theatre in which God's majesty in all spheres of life is displayed. Writing in his commentary on Genesis 1:1, Calvin draws the following four points to substantiate his stand on vocational calling:

[Sic First], After the world had been created, man was placed on it as in a theatre, that he, beholding above him and beneath the wonderful works of God, might reverently adore their Author. Secondly, that all things were ordained for the use of man, that he, being under deep obligation, might devote and dedicate himself entirely to obedience towards God. Thirdly, that he was endued with understanding and reason, that being distinguished from brute animals he might meditate on a better life and might even tend directly towards God; whose image he bore engraved on his own person (Calvin 1981:64).

These remarks affirm Calvin's view that the entire world, not a part or some parts of it, is God's theatre in which every person was placed for a purpose. In his commentary on Genesis 1:26, Calvin argues that, out of God's property, “... man was rich before he was born," and we are placed in the world for a purpose" (Calvin 1981:96). Stressing this, in his comment on Psalms 24:1, Calvin alludes:

As God, by His providence, preserves the world, the power of His government is alike extended to all, so that He ought to be 
worshiped by all as He also shows to all men without exception, the fatherly care he has about them (Calvin 1979:401).

It is a fundamental truth of the Bible that when creating inanimate and animate of every kind, arranging an innumerable variety of objects in admirable order, giving each creature a proper place to live in and earn a living, God appointed man to lord over the world (Institutes 1.14.20), implying that the world remains God's property. On the same point, Calvin explains:

... they have all been given us by the kindness of God and appointed for our use under the condition of being regarded as trusts, of which we must one day give account. We must, therefore, administer them as if we constantly heard the words sounding in our ears, "Give an account of your stewardship. At the same time, let us remember by whom the account is to be taken - viz. by him who, while he so highly commends abstinence, sobriety, frugality, and moderation, abominates luxury, pride, ostentation, and vanity; who approves of no administration ..." (Calvin 1979:401).

Based on these remarks, I want advance three points. First, Calvin understands that every person is a trustee of God's property. Secondly, by the virtue of being stewards, they will give an account on their stewardship on the day of judgement. Thirdly he is reminding us that while serving the Lord both in the Church and the world we should do as if we are hearing God's sounding saying, "You will give an account of your stewardship one day" (Institutes 1.14.22).

As already pointed out, the entire world - not just a part of it is a glorious theatre where God displays his sovereignty, majesty, wisdom, goodness, justice and mercy. Here the question is whether people are either actors or spectators. In a response to this question, Calvin correctly writes:

... while it becomes man seriously to employ his eyes in considering the works of God, since a place has been assigned him in this most glorious theatre that he may be a spectator of them, his special duty is to give ear to the Word, that he may" (Institutes 1.5.2).

He continues arguing: 
But as the greater part of mankind, enslaved by error, walk blindfold in this glorious theatre, he exclaims that it is a rare and singular wisdom to meditate carefully on these works of God, which many, who seem most sharp sighted in other respects, behold without profit. It is indeed true, that the brightest manifestation of divine glory finds not one genuine spectator among a hundred (Institutes 1.5.8).

Three things are certain in Calvin's remarks. First, not the church or the monastery but the entire world is God's glorious theatre in which he displays His wisdom, love and providence. Second every lawful activity in this theatre and through its God displays sovereignty, wisdom, authority, goodness, love, providence and provision. Third, when God said, "let them have dominion over the fish of the sea and over the birds of the heavens and over the livestock and over all the earth and over every creeping thing that creeps on the earth." Calvin warns all Christians that:

... being placed in this most beautiful theatre, let us not decline to take a pious delight in the clear and manifest works of God. For, though not the chief, it is, in point of order, the first evidence of faiths to remember to which side so ever we turn, that all which meets the eye is the work of God, and at the same time to meditate with pious care on the end which God had in view in creating it (Institutes 1.14.20).

Calvin's views are carried on in his commentary on Ephesians 2:11-13 especially where he writes:

We are in the world where God displays such an abundance of miracles by which he desires to be known and worshipped and yet nevertheless we behave like beasts and persist like blockheads without any understanding, not knowing the God that made us and fashioned us, even him that displays and shows himself in all his creatures both above and beneath (Calvin 1975:182).

These remarks are consistent with the assertion that God created the world for the purpose of displaying his excellences. This follows that the beauty and perfections of physical world were originally intended to mirror His 
beauty and perfection. In this theatre, by virtue of His calling all ought to display His excellences.

\section{God's calling: The basis of accountability and transparency of public servants}

As mentioned earlier, Calvin's reasonable work ethic is a development of biblical injunctions, and particularly Paul's letter to the Corinthian Christians where he wrote: "Each one should retain the place in life that the Lord assigned to him and to which God has called him" (1 Cor 7:17). Repeatedly stated, according to Calvin the entire world is the office place, workplace and work of every creature including a human being. In his interpretation of Matthew 25:15, he writes:

From this history we learn that God, by the power of his Word and his Spirit, created the heavens and the earth out of nothing; that thereafter he produced things inanimate and animate of every kind, arranging an innumerable variety of objects in admirable order, giving each kind its proper nature, office, place, and station ..." (Institutes 1.14.20)

Calvin notes that in His divine wisdom, after creating, God purposely arranged all creatures in an orderly manner and decently put them in their right places. Regarding people's assignment, he further observes:

It is because God, as he has assigned to everyone his place and has bestowed on him natural gifts, gives him also this or the other injunction, employs him in the management of affairs, raises him to various offices ... (Calvin 1943:442).

Throughout this paper, I have stressed Calvin's belief that from the beginning God called people and assigned every person, his duties in different spheres of life inter alia to prevent general confusion and disorder in the society with a purpose of ensuring that every person may carry out his office with great willingness and more courage. And every person in his respective sphere of life shows more patience and will overcome the difficulties, cares, miseries and anxieties. To substantiate his position, in his commentary of 2 Thessalonians 3:10, Calvin says: 
It is also to be observed that there are different types of ways of labouring. For whoever aids the society of men by his industry, or either by ruling his family, or by administering public or private affairs, or by counselling, or by teaching, or in any other way, is not to be reckoned among the idles (Calvin 1981:354).

Underlying point of Calvin's biblical view of occupational calling is the biblical truth that God places individuals where He wants them to be and that that every person's occupation is a post and a station assigned to him by God. Calvin and other Reformers freed vocation from the confines of the church's walls.

Referring to various kinds of calling, Calvin argues:

We should also note that there are different kinds of work. Anyone who benefits human society by his industry, either by ruling his family, administering public or private business, giving counsel, teaching, or in any other way, is not to be regarded as having no occupation. It is the inactive drones whom Paul is berating ..." (Calvin's 1980:2).

Seemingly Calvin did not make mistake of idealising manual work and despising non-manual work: He sounds a strong warning to all people:

... that no one may presume to overstep his proper limits; he has distinguished the different modes of life by the name of callings. Every man's mode of life, therefore, is a kind of station assigned him by the Lord that he may not be always driven about at random. So necessary is this distinction, that all our actions are thereby estimated in his sight, and often in a very different way from that in which human reason or philosophy would estimate them (Institutes 3.10.6).

Having envisaged what ought to be in the minds of some workers, he observes:

They feel how wonderfully God is working in them, and their own experience tells them of the vast variety of gifts which they owe to his liberality. Whether they will or not, they cannot but know that 
these are proofs of his Godhead, and yet they inwardly suppress them (Institutes 1.5.2).

In view of these remarks, two points can be recalled from Calvin words. First God assigned each inanimate and animate of every kind of office, place, and station. Second, a saying that "God gave each kind its proper nature, office, place, and station" shows there will be different jobs, a variety of employment and posts and positions. Finally, Calvin also warns:

Accordingly, Paul, not without cause, admonishes us to use this world without abusing it, and to buy possessions as if we were selling them (1 Cor. 7:30, 31). But as this is a slippery place, and there is great danger of falling on either side, let us fix our feet where we can stand safely (Institutes 1.5.2).

In his written sermon on vocation, he writes:

Now to this, St Paul adds another warning (as I have already) by which he rebukes the common vices that are contrary to the rule our Lord has given us, in order that we should live as God's children, knowing that to this we are called (Calvin 1975: 451).

To give further details, he says:

And now he speaks of the deceits, robberies, and exhortations that are committed when every man is too much given up to his own gain and has no conscience about harming other men. Let him then that stole (he says) steal no more, but rather let him labour with his hands to do things that are good and profitable and by means of which he may succour them that have need (Calvin 1975:451).

Calvin's remarks probably imply that we have economic calling in which we must not mismanage or misuse or misallocate or excessively use resources that God has given to us. It is crystal clear that everyone cannot take all the jobs or occupy posts or positions or share jobs with his relatives, brothers or friends. What God expects of us is that we should acquire jobs honestly and earn one daily living noting that even for Calvin the work of the shoemaker and the barber has full dignity as the work God calls some to do.

Unlike Luther who just merely popularizes the understanding that serving as a cobbler, mother, silversmith, milkmaid, farmer, chimney sweep, sailor, 
teacher, judge, driver is as important as monks, nuns, cardinals of the pope or kings, Calvin sees every kind of occupation calling as a basis of accountability and transparency (Tawings 1947:102-9). He then offers the following warning to general Christian workers and professionals:

Let everyone consider the obligation which he has not only to this church but also to the city, which you have promised to serve in a diversity as well as in prosperity; thus, let each keep by his vocation and not endeavour to retire from it not to enter into cabals (Calvin 1855-57:260).

In support of the above he adds:

For when people go underground to seek for shifts, they may say indeed that they did not reflect and that they did not aim at or that. But let them consider the obligation that they have here contracted before God (Calvin 1855-57:260).

Notably, I want to advance three comments in connection with the quotations. First, people have obligations to not only to God through the church but also through the provision to service to the world. Second, in line with Luther's view the world could be filled with service to God if every person could understand his calling as serving God through serves in the world and the church. Third, calling demands accountability to God and to those whom He calls. Calvin writes:

It is not within our plan to enumerate examples, but let it be sufficient to know that the principle and basis of right conduct in every civil case is our calling by the Lord ... He who disregards his calling will never keep the straight path in the duties of his work ... There will be no consistency in the various part of his life ... Our present life will be best regulated, if we always keep our calling in mind (Calvin 1550:95).

Calvin's emphasis that God's call is a basis of learning to be accountable and transparent primarily to God (the One) who places them provides focus for life, encouraging people to commit their energy, knowledge, skills and professionalism and to do what they are called to do. 
The Lord Lord's calling is in everything the beginning and foundation of well-being. If there is anyone who will not direct himself to it, he will never hold to the straight path in his duties (Institutes 3.10.2).

According to Calvin, all people have a lawful call in life: they are called to glorify God in all things, even in earthly labours not only in the ecclesiastical spheres. Christians are called to work hard in whatever vocation they have and be accountable to the One who called them.

\section{The call of scientists, social science researchers and technologists}

Calvin's sphere of influence that take the Scripture as a basis for general physical models dealing with the origin and nature of the heavens. Clearly, he believes that science and research are gifts to mankind and that nonChristian are just capable of just discovering scientific truth for Christians. His conviction that God is Lord over all of life underscores his point of departure. The rationale for establishing this specifically Christian, i.e. biblical, model of physics is based on the idea that God, like every artist, would be best equipped to explain his own work, and that he does so in the Scripture. In the Institutes, Calvin asserts:

If the Lord has willed that we be helped in physics, dialectic, mathematics, and other disciplines, by the work and ministry of the ungodly, let us use this assistance (Institutes 1.5.2).

Drawing on Calvin's assertion that God has willed the study of physics, dialectic, mathematics, and othernon-theologicaldisciplines, this affirms that God's call cannot be restricted to clerical ministry or ecclesiastic functions. It may thus be added that Calvin gives a fundamental legitimization to the physical and social sciences in that they may be seen as a means of discerning the wise hand of God, thus enhancing belief both belief of his existence and worship. Thus, to neglect the discoveries of non-Christians simply because of their lack of faith is according to him, to be guilty of sloth (Institutes 1.5.2).

About the anthropological significance of science, medicine, astronomy, he comments: 
In attestation of his wondrous wisdom, both the heavens and the earth present us with innumerable proofs not only those more recondite proofs which astronomy, medicine, and all the natural sciences, are designed to illustrate, but proofs which force themselves on the notice of the most illiterate peasant, who cannot open his eyes without seeing them (Institutes 1.5.2).

Finally, he argues:

It is true, indeed, that those who are more or less intimately acquainted with those liberal studies are thereby assisted and enabled to obtain a deeper insight into the secret workings of divine wisdom. No man, however, though he ignorant of these, is incapacitated for discerning such proofs of creative wisdom as may well cause him to break forth in admiration of the Creator (Institutes 1.5.2).

In the light of these two remarks one may realize that there a close link between calling and sciences, scientific research and technologies. It is true that the study of astronomy, medicine and all other natural sciences primarily assist in uncovering further evidence of the orderliness of creation and the wisdom of God in addition to helping people to appreciate the greatness and mercy of God. Calvin is very quick to point out that those who undertake scientific studies should realise that it is a calling from God that determines their work. On this he gives the following exhortation:

Accordingly, Paul, not without cause, admonishes us to use this world without abusing, and to buy possessions as if we were selling them (1 Cor. 7:30, 31). But as this is a slippery place, and there is great danger of falling on either side, let us fix our feet where we can stand safely (Institutes 3.10.1).

Through the remarks, Calvin commends the scientific study of physics, dialectic, mathematics, and other disciplines as a means of discerning the wiser hand of God. Second, the study of science, in Calvin's view increases our awareness of God's providence and love for mankind. Third, in discharging their duties scientists, researchers and technologists should understand that God has placed each of them at a certain post for a purpose 
and that they are primarily accountable to Him for whatever information and data they are collecting.

\section{The call of the judiciary, security and military personnel and other civil servants}

During the days of Calvin and other Reformers, there arose Anabaptist movement which believed that service in courts, trade, or civil arenas is not a part of calling. In his Institutes 4.20.6, Calvin stresses God established magistracy for the benefit of the republican and the people. Therefore, administrators of the civil government, according to Calvin, are simply God's representatives and His nominees. For him being a magistrate is "by far the most honourable of all callings in the whole life of mortal man" (Institutes 4.20.4). On the same, he elaborates:

... those who bear the office of magistrate are called gods, let no one suppose that there is little weight in that appellation. It is thereby intimated that they have a commission from God, that they are invested with divine authority, and, in fact, represent the person of God, as whose substitutes they in a manner act (Institutes 4.20.4)

Citing the Old Testament, Calvin further states that saints, some of whom hold the offices of magistrates among a free people, as Moses, Joshua, and the Judges, their functions are approved by the Lord and their office in the sight of God, is not only the sacred and lawful, but the most sacred, and by far the most honourable, of all stations (cf. Institutes 4.20.4). Having noted that, in many societies, the weak have little or no redress against the powerful, Calvin urges Christians to avail themselves to public courts and seek God's justice (c.f. Institutes 4.20.17).

\section{The call of politicians, legislators and advocates}

Prior to the Reformation, Christianity taught that civil rulers and other local and regional leaders were free to do virtually whatever they wanted. Yet in the scriptures and in the teaching of Calvin and other Reformers, politicians and legislators hold their offices as result of God calling implying that they are accountable to God and to their electorates. Clearly, as also noted above, Calvin has a high view of the vocation of what today we might 
call politicians. Commenting on examples from the Old Testament, he writes:

This is not a quibble of mine but is the interpretation of Christ. "If Scripture" says he, "called them Gods, to whom the word of God came." What is this but that the business was committed to them by God, to serve him in their office, and (as Moses and Jehoshaphat said to the judges whom they were appointing over each of the cities of Judah) to exercise judgment, not for man, but for God? To the same effect Wisdom affirms, by the mouth of Solomon (Institutes 4.20.4).

Finally, he says:

To this, we may add the examples of saints, some of whom held the offices of kings, as David, Josiah, and Hezekiah; others of governors, as Joseph and Daniel ... among a free people, as Moses, Joshua, and the Judges. Their functions were expressly approved by the Lord. Wherefore no man can doubt that civil authority is, in the sight of God, not only sacred and lawful, but the most sacred, and by far the most honourable, of all stations in mortal life (Institutes 4.20.4).

Taken together these remarks, I want to point out three important things. First, we are notified about Calvin's high view of politicians and civil servant as servants and ministers of God rather than just mere servants of political parties or civil governments. Second, a lawful holding of public office is orchestrated by God's calling. Third, because the civil government is instituted by God, those who discharge service are His servants or ministers.

Although he is convinced that the Bible does not prescribe a certain form of civil government, Calvin favours a combination of democracy and aristocracy but appreciates the advantages of democracy. He also sees tyranny as a demon that stalks the state, seeking to possess it and he adds that the tyranny threatens whenever power is in the hands of the few (Institutes 4.20.25). To him and of course other Reformers, power unchecked is power unjustified and add that absolute power corrupt those who hold it. In his conclusion, Calvin also notes that since absolute power corrupts those who hold it, such leaders cannot not call themselves 'ministers of God'. To minimize the misuse of political power and public office, Calvin proposes 
for the existence of several government arms and political institutions to provide checks and balances. He warns that if rulers revolt against God, they lose their right and authority and must be deposed.

Drawing on Romans 13:3, Calvin exhorts Christian citizens to accept that a wicked prince is the result of divine judgment visited upon the governed as punishment for their sins: 'For since the wicked prince is the Lord's scourge to punish the sins of the people, let us remember that it happens through our fault that this excellent blessing of God is turned into a curse. In his advice to Christians in Romans 13:7 Calvin writes:

... we ought to obey kings and governors, whoever they may be, not because we are constrained, but because it is a service acceptable to God; for he will have them not only to be feared, but also honourable by a voluntary respect (Calvin 1981: 482)

It may now be necessary to mention that in the modern world, many politicians and public servants have little or no idea that they are called to serve God during their term of office. On this Calvin warn political leaders:

"At the same time never abuse their power, by harassing the good and innocent ... For as they are deputed by God and do business, they must give an account to Him: and then the ministration which they are therefore, debtors also to them (Calvin 1981:480, 481).

Here Calvin has highlighted that politicians, unlike other public officers, serve God in sustaining society, contrary to the common understanding in which many people including Calvinists seem to assert that in discharging duties private and public officers serve organisations, communities, societies, nations or their government. Calvin then quoted Paul when he is exhorting Timothy that prayers should be honestly and regularly offered up in the church for kings and princes (Institutes 4.24.8).

Calvin consistently warns that no one ought to doubt that political and civil positions is a calling not only holy and lawful before God but also the most sacred and by far the most honourable of all callings in the whole life of mortal men. Such understanding could have led many Christian politicians and civil servants to learn to be accountable not only to those who appointed or vote for them but to God the One who called. 
Let us come to the subject of the call of parliamentarians. Calvin shows a deep concern on how Christian legislators should conduct their business. He explains that next to the magistracy in the civil service come the sinews of the commonwealth, the souls (Institutes 4.20.14). He comments:

In states, the thing next in importance to the magistrates is laws, the strongest sinews of government ..., without which, the office of the magistrate exist; just as, on the other hand, laws have no vigour without the magistrate. Hence nothing could be said more truly than that the law is a dumb magistrate, the magistrate a living law. As I have undertaken to describe the laws by which Christian polity is to be governed, there is no reason to expect from me a long discussion on the best kind of laws (Institutes 4.20.14).

It is to be noted, moreover that Calvin makes a point that those who have calling to promulgate or enact laws must do so with reference to God, the genuine Lawgiver (Institutes 4.20.14). It now remains for us to examine what he elaborates:

The subject is of vast extent and belongs not to this place. I will only briefly observe, in passing, what the laws are which may be piously used with reference to God, and duly administered among men (Institutes 4.20.14).

Turning to the question of relationship between the Word of God and constitutions and how the latter can be promulgated in line with the God's universal Law particularly the Decalogue, he argues:

For there are some who deny that any commonwealth is rightly framed which neglects the Law of Moses and is ruled by the common law of nations. How perilous and seditious these views are, let others see: for me it is enough to demonstrate that they are stupid and false. We must attend to the well-known division which distributes the whole law of God, as promulgated by Moses, into the moral, the ceremonial, and the judicial law, and we must attend to each of these parts, in order to understand how far they do, or do not, pertain to us (Institutes 4.20.14).

In his summary, the supremacy of kings, princes and other officials is the ordinance of God and that in performing their offices, in sustaining 
the society; they are primarily serving the living Lord and the people on the ground. The three arms of the government - (1) the cabinet (2) the legislature and (3) judiciary in the modern world were ordained to sustain the society of God manner.

\section{The call of farmers, businessmen, traders and bankers}

Calvin believes that agriculture and crafts are normal human activities. Calvin frames his theology of economic against the background of the medieval theology which claims traders and bankers are free to charge at any rate, and that doing business and banking is not part of calling. Quoting Ecclesiasticus 26:29, the $16^{\text {th }}$ century Anabaptists asserted that a Christian merchant could hardly keep from doing wrong, nor was a tradesman innocent from sin. Calvin does not subscribe to this erroneous teaching.

Significantly, in his comments on Exodus 22:25, Leviticus 25:35-38 and Deuteronomy 23:19-20, Calvin points out that the poor must be protected from abuse of usurers and the powerful and the charity to the poor must be proved not as a loan because they cannot make a return in kind (Calvin's 1981:679-683). As noted elsewhere, he does not accept the idea that usury or moneylending to ever be a man's full-time job:

With respect to usury, it is scarcely possible to find in the world a usurer who is not at the same time and extortion and addicted to unlawful and dishonourable gain. Accordingly, Cato of old justly the practice and killing of men in the same rank of criminality, for the object of this class of people is to suck the blood of other men (Calvin 1981:212, 213)

A little later he writes:

It is also a very strange and shameful thing that while all other men obtain the means of their subsistence with much toil, while ploughmen fatigue themselves by their daily occupations, and craftsmen serve the community by the sweat of their brow, and merchants not only employ themselves in labours but also expose themselves to many inconveniences and dangers, that usurers should sit at their ease without doing anything and receive tribute from the labour of all other people (Calvin 1981:213). 
Clearly Calvin does not accept that moneylending as a job. Neither does he approve it to be a calling. He warns that it is extremely wrong to permit anyone to draw to himself the benefits of other people's labour without contributing by his own labour or skill to the benefit of society.

On charging interest, Calvin strongly condemns the charging of excessive interest, and the charging of interest to a poor man, and the demanding of excessive security' but otherwise he teaches that the taking of interest is lawful. As a biblical scholar, Calvin was convinced that God does not condemn every form of profit as unjust. He makes his point clearly asserting that it is wrong to permit anyone to draw to himself the benefits of other people's labour without contributing by his own labour or skill to the benefit of society (Institutes 3.10.6).

\section{The call of fraudulent thieves and oppressive employers?}

Calvin and Reformers had a high view of lawful business against fraudulent business and unlawful acquisition of property. In his exposition of the 8th commandment in the book of Exodus 20:15, he writes at length:

... to acquire nothing but honest and lawful gain; if we long not to grow rich by injustice, nor to plunder our neighbour of his goods, that our own may thereby be increased; if we hasten not to heap up wealth cruelly wrung from the blood of others; if we do not, by means lawful and unlawful, with excessive eagerness scrape together whatever may glut our avarice or meet our prodigality (Calvin 1981:683).

He continues asserting:

[On the other hand], let it be our constant aim faithfully to lend our counsel and aid to all so as to assist them in retaining their property; or if we have to do with the perfidious or crafty, let us rather be prepared to yield somewhat of our right than to contend with them (Calvin 1981:683).

In his preaching on the $8^{\text {th }}$ commandments, Calvin explains that, the title "thief" should preferably be used in order to make us regard with hate all fraud, graft and any kind of wrong that we know we could do against other people (Calvin'2011:186). He also adds: 
In any event the man is a thief inasmuch as he has acted out of a bad conscience, regardless whether anyone condemns him... God not will nor neglect to judge as a thief anyone who has taken advantage of a simple man, or has sold him goods in an underhand way, seeing that he has outwitted him through a fault judgement (Calvin'2011:188).

He also argues:

Anyone who also overcharges an illiterate person is equally a thief. Moreover, if an artisan makes a faulty good and the buyer cannot perceive the flaw or especially if someone takes whatever he can and sells what unquestionably doesn't belong to him, [justifying it on the basis] that he is dealing with a rich man who has a full purse, it's all the same (Calvin 2011:186).

Consequently, a caution is here introduced to Christian traders and businesspeople:

Therefore, if a man engages in any of these practices-although he may be able to get away with it in the world's eyes-the judgment of God will nevertheless run its course (Calvin 2011:187).

Calvin was writing against conducting fraudulent business and unlawful acquiring of property, noting doing so was a breach of the second law of the summary of the Ten Commandments, "love your neighbour." Not only that is he referring to people who secretly teal the properly of others but also those who seek for gain from the loss of others, accumulating wealth by unlawful practices. He finally denounces all unjust means of gain money, property or position. The same applies to employers who are offering low wages and salaries to desperate employees.

\section{Concluding remarks}

This article has affirmed that Calvin held a high dynamic view of calling, believing that every Christian has a vocational calling to serve God not only in the church but in the world in every sphere of human life. This should lead us to the following concluding question: What could Calvin commend to Christian politicians, public servants today? I now proposed what Calvin could have said to us. First, obviously Calvin could make them 
become aware that God's' calling is not restricted to prophets, apostles, pastors, reverends and bishops. Second, he could have urged those who realise that they are called to live out their faith and express it wherever they may be. Third, he could have made it clear that every worker, employer, employer, trader, banker is accountable to primarily to God. Fourth, in his final remark, he could commend Christians to adopt the Reformers' doctrine of occupational calling rather than that of the medieval Church and bearing in mind what Calvin has written that "[God] has assigned distinct duties to each in the different modes of life"(Calvin 1943:442).

\section{Primary sources}

Calvin, J 1843. Calvin's Commentary on book of Psalms translated by James Anderson (1979). Grand Rapids, Michigan: Baker Book house.

Calvin, J 1843. Calvin's Commentary on the book of Exodus, Leviticus and Deuteronomy translated by Charles B. Bingham (1981). Grand Rapids, Michigan: Baker Book house.

Calvin, J 1843. Calvin's Commentary on the book of Genesis translated by John King (1981). Grand Rapids, Michigan: Baker Book house.

Calvin, J 1843. Calvin's Commentary on the Gospels of Matthew, Mark and Luke translated by William Pringle (1981). Grand Rapids, Michigan: Baker Book house.

Calvin, J 1843. Calvin's Commentary on the Gospels of Matthew, Mark and Luke translated by William Pringle (1995). Grand Rapids, Michigan: Baker Book house.

Calvin, J 1855-7. Letters of John Calvin: Selected from the Bonnet Edition with an introductory biographical sketch. Grand Rapids, Michigan: William B. Eerdmans Publishing.

Calvin, J 1980. Calvin's Commentaries on Thessalonians translated by R. McKenzie. Grand Rapids: William B. Eerdmans Publishing.

Calvin, J 2011. John Calvin's Sermons on Ephesians. Edinburg: Banner of the Truth Trust. 
Calvin, J 2011. Sermons on the Ten Commandments translated by Benjamin Farley. Pelham: Solid Ground.

Calvin, J 1956. Commentaries on the Epistle to the Romans, Chapter Xlll:2 On God and Political Duty. Indianapolis: Bobbs-Merrill.

Calvin, J 1550. Golden Booklet of the true Christian Life translated by Henry Van Andel (1990). Grand Rapids, Michigan: Baker Book house.

Calvin, J 1538. Institutes of Christian Religion translated by John $\mathrm{T}$. McNeill (ed.), translated by F.L. Battles (1960). Louisville: John Knox Press.

Calvin, J 1843. Calvin's Commentary on Paul's letter to Timothy translated by William Pringle (1981). Grand Rapids, Michigan: Baker Book house.

Calvin, J. Calvin's Commentary on Paul's letter to the Romans translated by John Owen (1981). Michigan: Baker Book house.

Calvin, J. Calvin's Commentary on the Book of Psalms translated by John Pringle (1981). Grand Rapids, Michigan: Baker Book house.

Calvin, J. Calvin's Commentary on the Book of Prophet Joel translated by John Own (19581). Grand Rapids, Michigan: Banner of Truth Trust.

Calvin, J. Calvin's Commentary on the letter to the Corinthians translated by John Pringle (1981). Grand Rapids, Michigan: Baker Book house.

Calvin, J. Calvin's Commentary on the letter to the Thessalonians translated by John Pringle (1981). Grand Rapids, Michigan: Baker Book house.

Luther, M 1981. Luther's commentary on the Book of Genesis translated by John Pringle (1981). Grand Rapids, Michigan: Baker Book house.

Martin, L 1520. Open Letter to the Christian Nobility of the German Nation Concerning the Reform of the Christian Estate (1520). [Online]. Available: https://web.stanford.edu/ jsabol/certainty/readings/LutherChristianNobility.pdf [Accessed: 6 May 2019]. 


\section{Secondary sources}

Aristotle, 1925. Nicomachean Ethics. New York: Oxford University Press.

Barnette, HB 1965. Has God Called You? Nashville: Bradman Press. 